\title{
Urban Population Development in Germany (2000-2014): The Contribution of Migration by Age and Citizenship to Reurbanisation*
}

\section{Paul Gans}

\begin{abstract}
The increase of the population of large German cities between 2000 and 2014 indicates a reurbanisation process in line with the concept of the "growing city". This exploratory investigation will analyse the influence of internal and external migration on the population development of the German urban system by applying descriptive and statistical methods, going beyond the mere observation of selected cities.

This paper shows that reurbanisation in Germany has resulted from various ageand citizenship-dependent combinations of spatial population movements, which in turn express different location advantages and disadvantages. The structural change towards a knowledge economy, the expansion of education, and changing living concepts on the demand versus new urbanistic planning concepts on the supply side strengthen the affinity of different population groups for urban living. This new attractiveness of cities seems to be most distinct among young adults' motives for living in cities or not. Furthermore, the dynamics of these processes are also dependent upon conditions on the national and international levels. Thus, before the economic and financial crisis 2009 the balances of internal migration of the German as well as foreign population had a decisive influence on the dynamics, in-migration surpluses from abroad rose considerably after 2009. With the rising numbers of asylum seekers, state-controlled residence allocations as well as migrant networks are increasingly important for the population development of cities. At the same time, especially in cities with at least 500,000 inhabitants, ongoing growth is creating shortages on the housing and real estate markets, which tend to counteract the population growth.
\end{abstract}

Keywords: Urban population development · Germany · Urban system · Reurbanisation · Suburbanisation · Internal migration · External migration · German citizens · Foreign citizens · Age groups · Housing market $\cdot$ Labour market

\footnotetext{
This article belongs to a special issue on reurbanisation.
} 


\section{Introduction}

Around the turn of the millennium, a reversal in the population development trends of German cities took place (Siedentop 2008: 193). After years of suburbanisation and counterurbanisation with declining population figures in large cities, the tendency changed: In the period between 2000 and 2014, urban populations increased by 3.8 per mille annually, and that of all district-free cities ("Kreisfreie Städte", ${ }^{1}$ e.g. Stuttgart or Heidelberg) by one per mille (Table 1). Compared to this, the increase in urban districts $(0.8 \% \mathrm{o})$ - predominantly belonging to the surrounding areas of the large cities - is smaller. Rural districts are characterised by population declines (those with higher population densities by $-2.1 \%$, those with lower population densities by $-3.7 \%$ ), and the total population of Germany is stagnating. In Table 1, the increase of the average annual growth rate by size of district-free cities, the considerable differences in the development in each size category and the decreasing amplitudes with the increasing population of the cities are particularly remarkable.

These varied population developments suggest inter- and intra-regional concentration processes. However - as a result of the simultaneous growth of urban districts - these processes are opposed by a deconcentration within agglomerations, at least to a certain extent. Based on the concept of the "growing city", a quantitative definition of reurbanisation (Matthes 2014) is used here, which describes a spatial approach to an increasing proportion of the population in the large or core cities in relation to their surrounding areas (Siedentop 2008; Herfert/Osterhage 2012). From a dynamic perspective, reurbanisation is understood here in the sense of the model of cyclic urban development by van den Berg et al. (1982) as is defined as a temporary spatial concentration process.

In the wake of the positive developments of population and employment in large cities since the turn of the century (Geppert/Gornig 2010), researchers from various disciplines forecast a slowdown of the ongoing suburbanisation processes (Gans) Kemper 2002). These suburbanisation processes had led to extensive urban sprawl

1 Since 2011, Germany has been administratively divided into 402 districts, 107 of which are district-free cities, cities not attached to an administrative district, and 295 administratively denominated rural districts. Rural districts are made up of several municipalities, some of which can also be cities. These so-called district towns are not considered in the survey due to data availability. District-free cities are divided into large cities with at least 100,000 inhabitants and medium-sized cities with less than 100,000. Large cities are the functional and economic centres of urban agglomerations in Germany and are further divided into categories of 100,000 to $199,999,200,000$ to $499,999,500,000$ to 999,999 and at least $1,000,000$ inhabitants. In this study, metropolitan cities are those cities with at least 500,000 inhabitants. Regardless of that, the Federal Institute for Research on Building, Urban Affairs and Spatial Development (BBSR) distinguishes four types of settlement structures for all German districts. Here, the classification is based on the population density of the districts, taking into account the density in the region in which the district is located: district-free cities, administratively denominated rural districts as urban districts (population density of at least 150 inhabitants $/ \mathrm{km}^{2}$ ) mostly in the surrounding areas of large cities, rural districts with a great proportion of densely populated areas (less than 150 inhabitants $/ \mathrm{km}^{2}$ ) and sparsely populated rural districts (less than $100 \mathrm{in}$ habitants $/ \mathrm{km}^{2}$ ). Therefore, district-free medium-sized cities can be classified as urban districts, rural districts with a great proportion of densely populated areas, or as sparsely populated rural districts. 
Tab. 1: Population development of district-free cities in Germany by city size, 2000-14

\begin{tabular}{|c|c|c|c|c|c|c|}
\hline $\begin{array}{l}\text { District-free cities by } \\
\text { number of inhabitants } \\
\text { as of } 31 \text { December } 2011\end{array}$ & $\begin{array}{l}\text { Annu } \\
\min \end{array}$ & $\begin{array}{l}\text { al average } \\
\text { lower } \\
\text { quartile }\end{array}$ & $\begin{array}{l}\text { e growth } \\
\text { median }\end{array}$ & $\begin{array}{l}\text { rate (per } \\
\text { upper } \\
\text { quartile }\end{array}$ & $\begin{array}{l}\text { max } \\
\text { mo0) }\end{array}$ & $\begin{array}{c}\text { Number of } \\
\text { districts }\end{array}$ \\
\hline \multicolumn{7}{|l|}{ Large cities } \\
\hline $1,000,000$ and more & 4.4 & 4.6 & 5.2 & 10.7 & 12.5 & 4 \\
\hline 500,000 to $1,000,000$ & -2.7 & -0.1 & 4.7 & 8.2 & 9.4 & 8 \\
\hline 200,000 to 500,000 & -6.7 & -3.7 & 0.9 & 4.9 & 10.9 & 25 \\
\hline 100,000 to 200,000 & -7.3 & -1.2 & 3.6 & 5.8 & 10.7 & 29 \\
\hline \multicolumn{7}{|l|}{ Medium sized cities } \\
\hline 50,000 to 100,000 & -15.9 & -7.7 & -1.1 & 2.3 & 8.8 & 23 \\
\hline 20,000 to 50,000 & -19.6 & -3.9 & 0.1 & 1.2 & 5.9 & 18 \\
\hline All district-free cities & -19.6 & -3.1 & 1,0 & 4.7 & 12.5 & 107 \\
\hline Germany & -19.6 & -4.4 & -0.1 & 2.8 & 12.5 & 402 \\
\hline
\end{tabular}

Source: BBSR 2016a; own calculations

with negative ecological consequences and intensified intra-regional segregation and economic disparities between the core city and the surrounding region (Gans 2005). However, the growth of urban districts by 0.8 per mille suggests - at least to a certain extent - a deconcentration of the population within agglomerations, thus indicating that processes of suburbanisation are still underway. Following the stages of urban development by van den Berg et al. (1982), one can assume simultaneous processes of re- and suburbanisation, as well as growth and shrinkage, in German district-free cities between 2000 and 2014.

This exploratory study aims to analyse these processes, which are largely determined by internal and external migration. Here, a spatial as well as temporal perspective must be provided. On the one hand, there are significant differences in population development within the urban system (Table 1), as well as questions about site-specific characteristics of district-free cities, which have a positive or negative impact on the development of population figures. On the other hand, economic distortions shape the dynamics of spatial population movements during the sample period. Since the financial and economic crisis of 2009, the attractiveness of Germany as a migrant destination has increased significantly (Gans/Pott 2018). Whilst until 2010, the external or international migration balance decreased continuously with negative values in the years 2008 and 2009, by 2014, the number of immigrants had doubled to just under 1.5 million, leading to a net migration of approximately 550,000 (Statistisches Bundesamt 2017). Ongoing population growth in many large cities since the year 2000 combined with low construction activity until 2010 has led to an increasingly tense situation on the residential housing market in several large cities (Rohland 2017: 32-33). In the coming years, rapidly rising land prices and rental property costs - additionally driven by favourable construction loans - could lead to deconcentration processes and relocations from district-free 
cities to the surrounding areas, despite the development of new housing areas or the building of new housing on vacant plots in the core cities, thus counteracting reurbanisation.

The main focus of this paper is to examine the dynamics of internal and external migration - further differentiated by age and citizenship - and the development of cities of different sizes. A main impetus for this article is the fact that many studies show that some population groups function as a motor for reurbanisation, whereas others counteract this trend (Kabisch et al. 2012; Gans 2015; Matthes 2014; Milbert) Sturm 2016). Overall, from 2000 to 2014, district-free cities achieved a migration surplus of 9.3 per mille, clearly exceeding the birth deficit of -6.1 per mille. The estimate of births and deaths for district-free cities from 2010 to 2014 is almost balanced at -0.5 per mille, for metropolitan cities it is slightly positive at 1.0 per mille. However, these values are surpassed by the migration surpluses of both district-free $(+7.8 \%$ o $)$ and metropolitan cities (+9.7\%o). The key questions therefore are: How important has internal and external migration been for these population trends? Which age groups and nationalities are increasing and decreasing urban growth?

First, the paper outlines the causes of population growth in cities. This is followed by the presentation of the data for the subsequent empirical analysis, which - in comparison to Herfert and Osterhage (2012), Sander (2014) or Busch (2016) examines district-free cities as elements of the urban system in Germany. Additionally, the study differentiates internal and external migration by migrants' age and nationality.

\section{Theoretical Background}

Signs of a reversal from urban population decline to urban growth have been evident in Western European countries and the United States since the 1980s (Frey 1988; Cheshire 1995). Ogden and Hall (2000) found a similar change in France in the 1990s for Lyon, Toulouse, Nice and Nantes. In this decade, the population developments of Chicago and New York also turned positive (Fishman 2005), and in England, those cities particularly affected by deindustrialisation - such as Manchester and Liverpool, but also Leeds, Newcastle and Sheffield - recorded population increases between 2001 and 2011 (Rae 2013). In Switzerland, Rérat (2012) observed urban population growth starting in 2000.

A number of factors have caused this urban growth since 2000 . It can be ascribed to a social change over the past years which, according to Brühl et al. (2005: 11), provides "the basis for a rediscovery of living in the city". ${ }^{2}$ The various dimensions that contribute to the renaissance and population growth of cities are based on, among other things, the changing needs of private households, economic restructuring as well as the knowledge economy and municipal strategies for strengthening the attractiveness of urban locations:

2 Direct quotes from German texts have been translated into English by the author. 


\section{Social Change}

Social change and its diverse impacts on household formation, employment and work relations as well as gender norms has modified the guiding principles and requirements for housing and living environments in favour of cities, thus weakening the process of suburbanisation (Brühl et al. 2005; Siebel 2008; Jessen/Siedentop 2018). A driving force behind this change is the pluralisation of living arrangements (Ogden/Hall 2000; Buzar et al. 2007; Haase et al. 2010). This development is characterised by an erosion of the "traditional" family and the increasing relevance of smaller household sizes, whether due to later marriage, increasing divorce rates or the increasing proportion of unmarried people and household forms with fewer members. At the same time, for young adults, the phase between moving out of their parents' house and possibly starting their own family (as well as the parents' "empty nest" phase) is becoming longer (Siebel 2010). Therefore, the period in which people live in growing or relatively large households is becoming shorter. Due to this, the timeframe in which they may be more open-minded to buying or building a house or moving to a residential suburban area is being reduced. With the growing importance of the knowledge economy, working relationships are changing to more temporary projects, fixed-term contracts, irregular working hours and high workplace mobility. Brake (2012: 24) characterises this change as follows: "It is becoming less common to have the one profession, the one workplace, the one job location, the one marriage, the never-changing working hours or shop opening hours". This destandardisation of the life course (Siebe/ 2010) changes the needs of private households, which are most likely met by the advantages of urban locations. Urban amenities - such as easy access to transport infrastructure, proximity to social and cultural scenes, retail facilities (Hesse 2010), educational institutions and workplaces - are important location factors for working couples with and without children, students, singles, single parents and the elderly (Häußermann/Siebel 1987; Brake 2012). It is of upmost importance to have a living environment that provides the possibility for an efficient organisation of everyday life, a certain degree of tranquillity, safety and environmental quality as well as a living environment that fulfils the need for infrastructural and social integration (Gans et al. 2008).

\section{Economic Change}

The change and restructuring in economy since the early 1980s resulting from globalisation and new communication and information technologies have promoted an emerging recentralisation in the United States, which, according to Frey (1988: 263), can be explained by "periphery-to-core" or "up the size hierarchy" migration streams from economically weak to economically strong regions or from small to large cities. However, this reversal of urban population development trends, which began in the 1980s, is not only dependent on the size of a city. Using the example of Europe, Cheshire (1995: 1058) emphasises the quality of life in cities, the importance of urban amenities and asks whether the growing knowledge economy will be able to attract highly qualified workers. The main prerequisites for this are access to 
research, higher education and training institutions as well as close collaboration of these institutions with corporations and companies from the same and other sectors. In this respect, cities have urbanisation as well as localisation advantages due to their functional diversity. These advantages increase with city size and enable the expansion and intensification of communication and information flows (Glaeser et al. 2001; Florida 2002; Storper/Scott 2009; Geppert/Gornig 2010; Brake 2012: 2425). The options described above form the basis of urban creative milieus, which place particular emphasis on specific areas or districts within large cities, despite globalisation and digitalisation (Brake 2012: 26). These places are particularly attractive for highly qualified and creative workers, including start-up entrepreneurs, and thus have a migration surplus of younger people such as 25 - to 30 -year-olds searching for their first job after graduating.

\section{Educational Expansion}

Another factor that has a positive effect on urban growth are institutions for further education. Between 2000 and 2015, the overall number of students in Germany increased from 1.8 million to 2.8 million (Statistisches Bundesamt 2016a). From the late 1990 s to 2013 , the percentage of freshmen at universities increased from 29 percent of the final grade of secondary schools to 53 percent (Simons/Weiden 2016: 264). Temporary spikes of student numbers resulted from the suspension of compulsory military service in 2011 , and, after 2012 , from a reduction of secondary school years in several federal states. The number of students who acquired their higher education entrance qualification abroad also increased by about 75 percent to almost 220,000 between 2000 and 2014 (BMI 2016: 75). This interaction of various factors led to an increase - at least temporarily - of the internal migration surplus of 18-25-year-olds in cities with universities, and, as a consequence, to a significant increase in the demand on the housing markets in those cities (Gans 2015; Simons/ Weiden 2016; Sander 2018). The influx of students and graduates causes changes in the composition of urban populations, as shown by various studies of EU member states and the United States (z.B. Ogden/Hall 2000; Birch 2005; Haase et al. 2010). Typically, the age structure rejuvenates, educational attainment increases, small household sizes gain in prominence, and alternative living arrangements such as shared flats or the cohabitation of young couples spread. This, in turn, can displace long-established low-income households (Schindler et al. 2012).

\section{Foreign Population}

International migrants are much more likely to move to metropolitan cities than internal migrants are. In 2013, the proportion of foreigners in metropolitan cities was 15.3 percent (13.9 percent in large cities), clearly outnumbering that of the rest of Germany, where it was 8.7 percent. In 2013, almost 27 percent of all foreigners in Germany lived in metropolitan cities (45 percent in the remaining large cities), and their share of the total population in metropolitan cities reached 15.2 percent (30 percent for large cities). This concentration results from the size of the urban la- 
bour market, differentiated employment opportunities irrespective of qualification requirements, the size, diversity and affordability of urban rental housing markets, and migrant networks which tend to be more effective in the case of ethnic diversity among foreign residents in large cities (Gans/Sch/ömer 2014; Jessen/Siedentop 2018). Birch (2005), Fishman (2005) or Rérat (2012) also refer to the importance of international migrants for urban growth and the related increasing diversity of the population. Fishman (2005) argues that immigration gives a positive impetus to the development of inner-city neighbourhoods which have experienced devaluation through deindustrialisation, suburbanisation and counterurbanisation of the 1960s and 1970s. Immigrants make use of the location advantages of these neighbourhoods (e.g. affordable living space and proximity to the core of the regional labour market), and by improving their economic situation invest in the quality of their neighbourhood. "These initial improvements encourage landlords to improve their rental properties, thus keeping older residents in the area and bringing in others" (Fishman 2005: 359). Small businesses open up close to the downtown economy, partly in formerly fallow areas, thus laying the foundations for a flexible urban economy with highly qualified workers, "whose jobs are replacing the lost world of urban mass production" (Fischman 2005: 359). In this case, urban development can be seen as a response to reurbanisation (Haase et al. 2010).

\section{Urban Development policy}

Public policy and municipal strategies for urban development also strengthen the attractiveness of urban residential areas as opposed to living in the surrounding suburban or rural areas. In 1971, a law promoting urban development (Städtebauförderungsgesetz) was implemented, aiming at improving the housing conditions for inhabitants of socially disadvantaged and structurally underdeveloped urban neighbourhoods (Harlander 2007). As a consequence, private property owners and the real estate industry started investing in housing stock outside of the designated housing programme areas. Since the 1980 s, cities have pursued urban development policies aimed at increasing the attractiveness of urban areas in terms of living, working and leisure activities. The reason behind this was that cities were facing a tightening of their financial scope due to relocation trends of high-income households and businesses to surrounding suburban areas. Up until today, cities have set up urban planning projects at varying levels, investing in undeveloped and conversion areas as well as developing industrial, transport or harbour areas, which had been falling into increasing disrepair since deindustrialisation in the 1970s. This strategy of cities with the aim of providing new areas for housing development primarily depends on whether such areas are available and by whom they are owned. It also depends on the guiding principles of urban planning in the city in question, such as "inner development before outer development" in the case of Stuttgart (Schol/ 2003: 12) or Liverpool (Rink et al. 2012: 172). In the UK, for example, strategic revitalisation objectives in urban development policy have had a long-term impact on urban growth since the 1970s. Similar to Germany, measures such as the modernisation of the housing stock, improvements of the living environment quality or 
the allocation of new development areas on brownfield land increase the attractiveness of urban residential locations (Rink et al. 2012; Rae 2013). Major events also serve as a catalyst for urban renewal. The Olympic Games in Barcelona in 1992 or in London in 2012, for example, had the aim to revitalise socially and economically disadvantaged neighbourhoods (Braun/Viehoff 2012: 6). At the same time, the cities hoped to permanently strengthen their attractiveness, e.g. through a higher degree of prestige and name recognition. In this sense, urban development policy is seen as the cause of reurbanisation (Haase et al. 2010).

\section{Increasing Real Estate Prices}

The decision to live in a city or its surrounding area is principally dependent on the monthly costs for rentals and on income (Matthes 2014; Jessen/Siedentop 2018). Expenses for the mobility of household members, such as higher taxation of fuel or the loss of government grants for owner-occupied residential property purchases lower the incentives for home ownership in dispersed locations. Declining interest rates since 2000 and the financial and economic crises have also increased the attractiveness of cities. With regards to real estate acquisition, low interest rates weaken the relative price advantage of surrounding areas compared to cities (Aring 2005). However, these points indicating a reurbanisation are opposed by rising prices, especially on the residential housing markets in large cities. Since 2009, rental costs in large cities have shown greater increases than elsewhere in Germany, especially in the so-called "A-cities" (Berlin, Munich, Hamburg, Cologne, Frankfurt/ Main, Düsseldorf, Stuttgart) (Rohland 2017; Schürt 2017: 7). Here, the demand for apartments exceeds the supply. Building plots have become a scarce and expensive good in large cities with population growth. In addition, extensive planning and approval procedures, staff shortages in building authorities, building regulations and civil society resistance movements make construction projects more expensive (Schürt 2017: 19). Oftentimes, private households in cities can neither afford an apartment nor a house that fulfils their requirements. Might the growing strain on the residential housing markets in large cities since 2010 increase the trend toward suburbanisation?

In the following, the above list of factors forms the basis for explaining the role of internal and external migration - differentiated by age and citizenship - in the rising population figures observed in district-free cities in Germany. However, the data availability sets a certain limit, which is why various aspects such as the influence of social change on reurbanisation cannot be considered to the same extent. Therefore, the main focus will be the consideration of location-specific conditions of cities, such as the structure of employment according to economic and professional sectors, the qualification of employees, educational institutions and the housing market. 


\section{Data and Method}

This investigation focuses on district-free cities in Germany, according to the territorial boundaries at the end of 2011. The empirical study is based on a special data set of the "continuous spatial observation" ("Laufende Raumbeobachtung", i.e. a long-term data set of the general living conditions in Germany across time and space), undertaken by the Federal Institute for Research on Building, Urban Affairs and Spatial Development (BBSR) between 1 January 2000 and 31 December 2014. The dataset - published in 2016 - covers population figures from 31 December 1999 to 31 December 2014. The analysis of the population, differentiated by citizenship and age group (which roughly correspond with stages within the life course such as childhood, adolescence, family formation or retirement), is possible for the years 2000-13. In addition, the following annual data are available: in- and out-migration, differentiated by internal and external migration, the total amount for the time period from 2000-14, differentiated by age groups (2000-13), German and foreign citizenship (2003-13), and differentiated by both features (2005-13).

The dataset also provides statistical information on key topics in spatial development (BBSR 2016b). The available indicators on the labour market, employment, education and housing market are the basis for the analyses in section 4 . However, the corresponding data are not available for every year in the period from 2000 to 2014 and not for every district-free city. Consequently, for characterisation - such as, for example, the proportion of employees in the creative industries who are subject to social insurance contributions in a district-free city - the average of the first available value and that of 2014 is calculated.

However, the census of 9 May 2011 makes it more difficult to carry out a thorough time series analysis because the determined population of 80.2 million for Germany was below the official forward projection of about 81.7 million based on the 1987 census. The census also delivered new population numbers at the district level, with some corrections being greater than others. Thus, the information on the number of inhabitants from 2000-11 is not fully comparable with the corresponding figures from 2012-14, in which the new census was taken into account. In order to be able to describe the population development, including internal and external migration, there are two possible approaches for every district-free city:

1. calculating the respective rates per calendar year in the time period 2000-11 on the basis of the census of 1987, and from 2012 onwards on the basis of the 2011 census, or

2. retroactively calculating population figures from the end of 2011 on the basis of the 2011 census.

However, it is not possible to carry out a meaningful back-calculation, as, for example, the information on births and deaths cannot be differentiated by nationality. With the application of the back-calculation, a corresponding analysis of urban population development would not be possible. Therefore, this paper uses the first 
procedure. In the case of ten district-free cities, this approach leads to a positive mean annual growth rate for the time period 2000-14, although the population size at the end of 2014 is lower than in 2000 which had been a consequence of comprehensive corrections following the 2011 census results.

Using descriptive methods, the exploratory study illustrates population development by size and temporal sequence, each differentiated by age and nationality, and captures the relationships between the trends and site-specific characteristics of the district-free cities with the help of correlation and regression analyses.

\section{$4 \quad$ Population Development of District-Free Cities (2000-14)}

\subsection{Reurbanisation and Metropolitanisation}

Most large cities have higher growth rates than the national average (see Table 1). The resulting spatial concentration process is especially noticeable in East Germany, where cities such as Leipzig and Dresden stand out in otherwise rather rural surroundings characterised by high population losses (see Table 2). In the case of Berlin, the sprawl is limited to a rather narrow strip of wealthy suburbs around the capital. A less prominent core-periphery structure - and thus a reurbanisation process according to van den Berg et al. (1982) - can also be found in the conurbations of West Germany (see Table 2). An absolute concentration in favour of the large cities is recorded as relatively high in the agglomerations of Frankfurt/Main and Cologne, but quite low for Hamburg and Bremen, where growth rates of the core city and the suburban area hardly vary. The region of Munich achieves its enormous population growth with very high external migration gains. Here, the surrounding region has an annual growth rate of 9.4 per mille, which is only surpassed by the increase of the number of inhabitants in the core city of Munich. In contrast, cities in the Ruhr area register a population decline. In the case of Dortmund, population development is stagnating but better than in the surrounding areas, thus, one can assume a relative concentration or reurbanisation. In Essen, however, the phase of reurbanisation does not apply (see Table 2).

A population development in favour of the larger cities - a metropolitanisation in favour of the large cities with at least 500,000 inhabitants in the sense of an "up the size hierarchy" trend according to Frey (1988: 263) - cannot be found in Table 2 , nor can it be derived from the correlation between the size of district-free cities and the rate of internal migration balance. The corresponding coefficient is not significant $(+0.017)$, because other factors, such as the city size, have - in different combinations and thus location- and/or region-specific characteristics - a high influence on in- and out-migrations within Germany (Gans/Schlömer 2014). Such factors include good to very good economic development (e.g. Munich, Stuttgart, Frankfurt/Main), unemployment rates of more than 10 percent (e.g. Bremen, Dortmund, Essen), noticeable improvements on the labour market in combination with simultaneously relaxed housing markets (Dresden, Leipzig) or the existence of universities and research institutions with a national reputation (e.g. Berlin, Munich, Hamburg, 
Tab. 2: $\quad$ Population development of the 12 large cities with at least 500,000 inhabitants (2011) and their surrounding areas, 2000-141

\begin{tabular}{|c|c|c|c|c|c|}
\hline \multirow[t]{2}{*}{$\begin{array}{l}\text { Core city ranked according } \\
\text { to size, } 31 \text { December } 2011\end{array}$} & \multicolumn{2}{|c|}{$\begin{array}{c}\text { Annual growth rate } \\
\text { per } 1,000\end{array}$} & \multicolumn{3}{|c|}{$\begin{array}{l}\text { Rate of migration balance } \\
\text { per } 1,000 \text { (Agglomeration) }\end{array}$} \\
\hline & Core city & Suburban area ${ }^{1}$ & Internal & External & Total \\
\hline Berlin & 5.1 & 2.8 & 1.3 & 3.7 & 5.0 \\
\hline Hamburg & 5.3 & 4.6 & 3.4 & 2.3 & 5.7 \\
\hline Munich & 12.7 & 9.4 & 2.6 & 7.6 & 10.2 \\
\hline Cologne & 5.8 & 0.9 & 4.3 & 0.7 & 5.0 \\
\hline Frankfurt/Main & 8.8 & 2.3 & 3.1 & 3.1 & 6.2 \\
\hline Düsseldorf & 4.4 & -0.4 & 2.8 & 2.5 & 5.3 \\
\hline Stuttgart & 5.9 & 3.4 & 2.3 & 2.8 & 5.1 \\
\hline Dortmund & -0.0 & -3.8 & -0.6 & 3.4 & 2.8 \\
\hline Bremen & 1.9 & 1.1 & 0.9 & 3.5 & 4.4 \\
\hline Essen & -2.0 & 0.5 & 0.8 & 1.9 & 2.7 \\
\hline Dresden & 9.5 & -6.7 & 7.4 & 1.8 & 9.2 \\
\hline Leipzig & 9.5 & -8.3 & 9.2 & 1.5 & 10.7 \\
\hline
\end{tabular}

1 The surrounding areas of large cities include the districts of the respective so-called spatial planning region ("Raumordnungsregion"), excluding district-free cities. In the case of the city-states, the bordering districts of the neighbouring spatial planning region are taken into account.

Source: BBSR 2016a; own calculations

Cologne, Dresden). In comparison to internal migration, the rate of external migration balance shows at best a weak positive correlation (+0.327). Accordingly, the respective rates of external migration balances tend to increase with the size of the district-free cities, which can be interpreted as a consequence of the large, differentiated labour and housing markets as well of the effectiveness of migrant networks. Large cities, with their high numbers of foreign nationals, function as hubs in migrant networks. Their effectiveness also depends on the location of the large cities in regard to the most important countries of origin, e.g. Munich towards Southeast Europe, Berlin towards Poland, or cities in southern Germany with a high proportion of people with a southern European migration background (Gans/Sch/ömer 2014).

The correlation between the population development of all district-free cities (2000-14) and selected variables relating to employment structure confirms the importance of economic structural change for urban growth (see Table 3). District-free cities with a high proportion of employees who pay social securitycontributions, work in business-related services and in creative industries and have academic degrees tend to grow in population. Cities with a high proportion of employees without a degree, with occupational activities in manufacturing and/or with higher unemployment rates are more likely to register population losses. District-free cities with institutions for further education show above-average growth rates. Further- 
Tab. 3: Correlation (Spearman's Rho') between the annual average growth rate (per 1,000) of large cities (2000-14) and selected variables regarding employment structure, education, housing market, household structure and city size

\begin{tabular}{cc}
\hline Variable & $\begin{array}{c}\text { Annual average growth rate } \\
\text { (per 1,000) }\end{array}$
\end{tabular}

Employment structure (proportion of employees

who are subject to social insurance contributions in)

Business-related services (in \%) ${ }^{2}$

$+0.551^{* *}$

Creative industries (in \%) ${ }^{3}$

Knowledge-driven industries (in \%) ${ }^{2}$

$+0.563^{* *}$

$+0.063$

Occupational activities in manufacturing (in \%, 2014)

$-0.397 * *$

Labour market

Unemployment (in \%) $)^{4}$

$-0.601 * *$

Unemployment (in \%, 2014)

$-0.559 * *$

Education

Employees without a qualification (in \%; 2014)

$+0.043$

Employees with an academic degree (in \%; 2014)

$+0,565^{* *}$

Number of students per 1,000 inhabitants ${ }^{4}$

$+0.447^{* *}$

Number of students per 1,000 inhabitants (2000)

$+0.480^{* *}$

Number of students per 1,000 inhabitants (2014)

$+0.425^{* *}$

Housing market

Change in living space per person (in \%; 2000-14)

$-0.665^{* *}$

Residential properties completed (in \%; 2011-14)

$+0.742^{* *}$

Building land prices (2013/14)

$0.677^{* *}$

Change in building land prices (2008/09-2013/14)

$0.424 * *$

Private household structure

Medium household size (2014) $-0.208^{*}$

Proportion of single-person households (2014) $+0.423^{* *}$

City size

$+0.312^{* *}$

1 level of significance: ${ }^{*} p<0.01 ; * p<0.05$;

2 average of 2009 and 2014;

3 average of 2008 and 2014;

4 average of 2000 and 2014

Source: $B B S R$ 2016b; own calculation

more, one can begin to see the negative side of the continuing population growth in district-free cities: The change in living space per person (2000-14) correlates negatively with the average annual growth rate, although many residential properties have been built in those district-free cities which have had above-average growth since 2011. The increasing occupancy rate can be interpreted as the replacement 
Fig. 1: Population development of district-free cities according to settlement structure, 2000-14

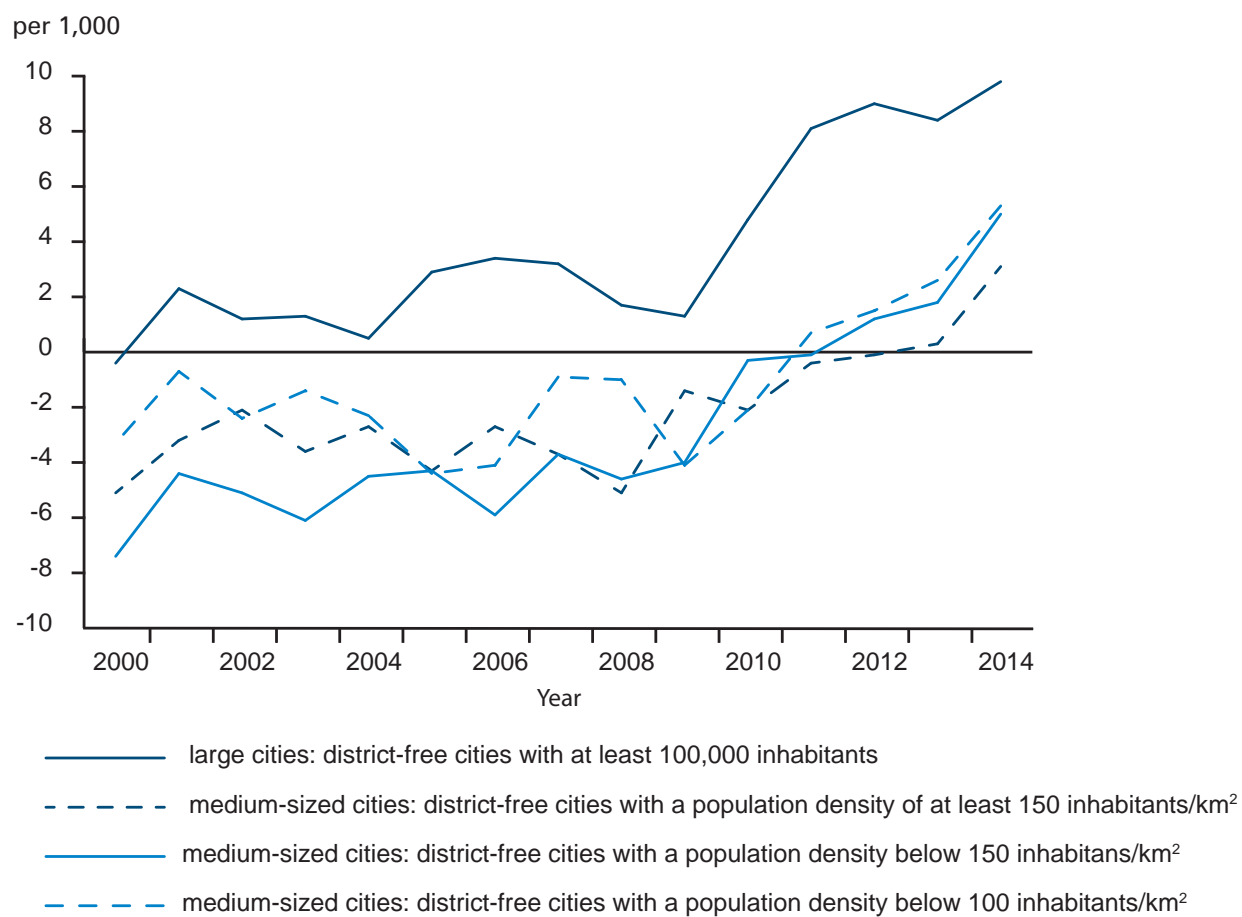

Source: BBSR 2016a; own calculations

of smaller household forms by larger ones, as well as a replacement of a singleperson household by shared households. This explanation could be ascribed to the positive correlation between the annual growth average and the proportion of single-person households (see Table 3), which reaches almost 50 percent in cities with higher- end land prices of more than $€ 365 / \mathrm{m}^{2}$ (2013/14, upper quartile) and significantly exceeds the corresponding value of 45 percent for all district-free cities. In addition, Table 3 shows that up until 2014, neither rising nor already high land prices had a dampening effect on urban growth.

Over time, the population development of district-free cities confirms a spatial concentration process in favour of large cities (see Fig. 1). Their annual growth rates are continuously higher than those of district-free cities with less than 100,000 inhabitants. Figure 1 also shows that the population growth of district-free cities after 2009 is significantly higher than before. Medium-sized cities registered a population decline up until 2009, while large cities were continuously growing (with the exception of 2000). After 2009 there was a remarkable turnaround in the up to then rather even population development (see Fig. 1). In all types of district-free cities, the rates started increasing continuously, whereas growth rates for large cities were 
still above those of medium-sized cities. Table 4 illustrates the striking differences of the population development in both periods by city size and settlement structure:

1. After 2009, the average growth rates for all district-free cities have risen, sharply for some.

2. District-free cities show higher population growth than any of the other district types.

3. The urban concentration process is intensifying, as the growth rates for large cities are noticeably higher than for urban districts in surrounding areas, and rural districts even show a decline in population figures. Adding to this, cities with at least 500,000 inhabitants show particularly high growth rates.

In summary, population development in Germany can be characterised as a reurbanisation process, especially in favour of the metropolitan cities. Considering Table 4, there is certainly evidence of Frey's (1988) "up the size hierarchy" trend. This result, however, requires a differentiated interpretation from city to city, as the differences in the population development of Dortmund, Bremen and Essen on the one hand, and Frankfurt/Main, Dresden and Leipzig on the other in the group with a size of 500,000 to less than 1 million inhabitants illustrate (see Table 2). Here, the respective economic and job market situations contribute to the trend, as does the relaxed housing market in the cases of Leipzig and Dresden (Hirschle/Schürt 2008). Local conditions also play a role in the cities with 200,000 to 500,000 inhabitants, which show comparatively low growth (see Table 4). Five cities in the Ruhr area belong to this category - Duisburg, Bochum, Wuppertal, Gelsenkirchen and Oberhausen. Their population has been declining by an annual average of 5.3 per mille

Tab. 4: Population development of district-free cities and other administrative districts by settlement structure in Germany, 2000-14

\begin{tabular}{lcc}
\hline District categories & \multicolumn{2}{c}{ Annual growth rate per 1,000 } \\
& $2000-09$ & $2010-14$ \\
\hline District-free cities by size & & \\
$1,000,000$ and more & 4.0 & 11.5 \\
500,000 to $1,000,000$ & 2.3 & 9.3 \\
200,000 to 500,000 & -0.4 & 4.7 \\
100,000 to 200,000 & 0.7 & 5.5 \\
Below 100,000 & -3.8 & 1.0 \\
All district-free cities & 1.2 & 7.3 \\
Urban districts & 0.5 & 1.4 \\
Rural districts & -3.2 & -0.2 \\
Germany & -0.4 & 2.2 \\
\hline
\end{tabular}

Source: BBSR 2016a; own calculation 
(2000-09) and 1.6 per mille (2010-14), mainly due to ongoing economic problems. The unemployment rates in these five cities changed only slightly between 2000 (median: 12.1 percent) and 2014 (median: 12.0 percent). The persistent challenges on their labour markets - compared to all district-free cities - are reflected by consistently higher unemployment rates than elsewhere in Germany, despite the ongoing favourable conditions in the country (2000: median 10.0 percent; 2014: median 7.9 percent).

The results so far are comparable to those of other studies (Glaeser et al. 2001; Florida 2002; Storper/Scott 2009; Brake 2012: 24-25). Large cities in particular are experiencing above-average growth. These cities' employment structure suggests that the knowledge economy plays an important role - they host centres for research and further education institutions, and their labour market is relatively relaxed. Major cities benefit greatly from these urbanisation advantages, so that in terms of the total population - analogous to Frey (1988) - one can refer to it as a development "up the size hierarchy" (see Table 3). The significant increase in momentum after 2009 points to the influence of further factors.

\subsection{Different Trends of Internal and External Migration by Citizenship}

The population development of district-free cities in Figure 1 results from changing national and international frameworks that - over time - have an effect on the different trends of internal and external migration, for German or foreign nationals (see Fig. 2). ${ }^{3}$ For German citizens, the balance between in- and out-migration was consistently slightly negative, hitting a minimum in 2004/06, when unemployment reached a peak in Germany at around 11 percent. However, the balance is quite low and only plays a subordinate role for the population development of district-free cities. For foreign nationals, external migration decreased in all types of districtfree cities until 2009, with slight losses in some cities in 2008 and 2009. As of 2010, the trend started reversing: The immigration surplus rose almost exponentially and reached about ten times its 2010 value in 2013.

The internal migration balances of the German population were positive throughout (2003-13) for large cities (see Fig. 2A). The gains continuously surpass the balances of the other district-free cities, which show a high fluctuation from year to year, and thus indicate a very high attractiveness of the residential areas in large cities, even though the balance of internal migration of the German population decreased significantly after 2011. The balances of foreign inhabitants are comparatively stable on a comparatively low level. As of 2010, very different trends can be seen in district-free cities independently of size or settlement structure.

If one is to take into account the factors that determine the differences described above - differences in intensity and time trends of internal and external migration balances relating to citizenship - economic and political changes at national and

3 Figure 2 A and B show significantly higher rates for foreign and German citizens, however, the effect of this difference on the development of the urban population is markedly reduced by the considerably larger number of German inhabitants overall. 
Fig. 2: Internal and external migration balances in district-free cities according to citizenship and to settlement structure, 2003-13

A - German Population
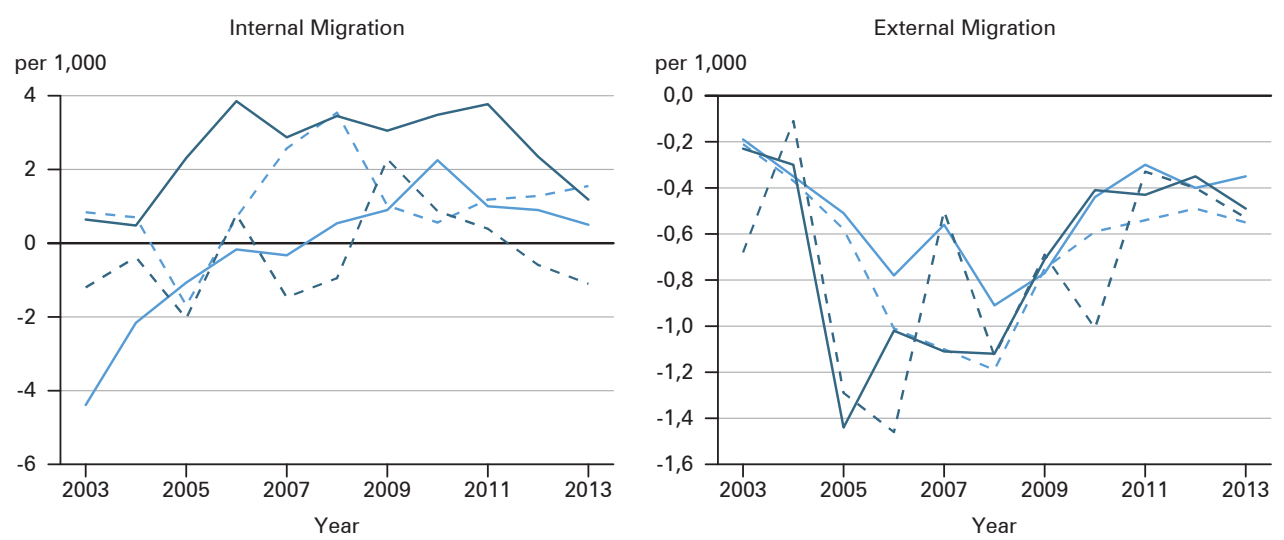

B - Foreign Population
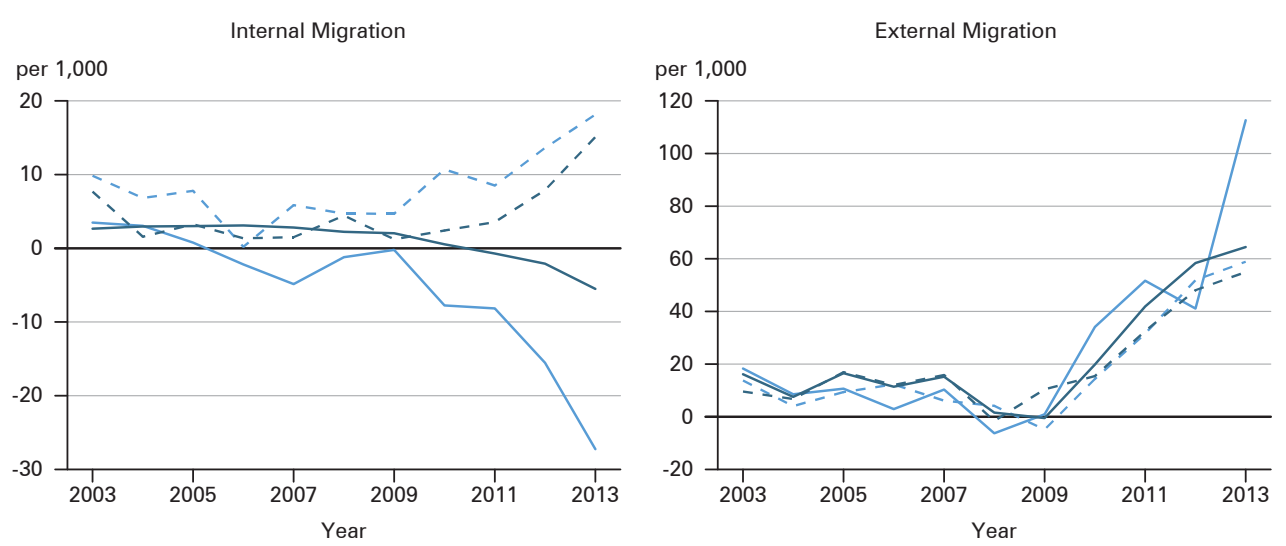

_ large cities: district-free cities with at least 100,000 inhabitants

- - - medium-sized cities: district-free cities with a population density of at least 150 inhabitants $/ \mathrm{km}^{2}$

- medium-sized cities: district-free cities with a population density below 150 inhabitans $/ \mathrm{km}^{2}$

- - - medium-sized cities: district-free cities with a population density below 100 inhabitants $/ \mathrm{km}^{2}$

Source: BBSR 2016a; own calculation

international levels must be taken into account. Until 2009, the situation on the German labour market was rather tense compared to other EU member states. Germany was thus not very attractive for migrant workers. This changed fundamentally with the financial and economic crisis (Gans/Pott 2018: 31; Rohland 2017: 36-37). As a result of the competitiveness of companies in Germany and labour market reforms, the demand for labour increased, as did the number of employees. Employment in Germany was particularly interesting for young adults from southern 
Europe. However, a much stronger factor in immigration numbers has been the EU's freedom of movement for workers for people coming from the countries of the 2004 and 2007 enlargement. In 2014, immigration from Poland was highest with 197,908 people, followed by Romania (191,861), Bulgaria $(77,790)$, Italy $(73,361)$, Hungary $(57,820)$ and Spain (41,091; Statistisches Bundesamt 2016b: 47). As conflicts in the Middle East and Africa have grown since 2011, by the end of 2014, the number of asylum applications in Germany had risen to about 202,000, the highest level in 15 years (BAMF 2017: 3). Asylum seekers are offered accommodation at reception centres upon arrival and are then distributed to other districts after their registration. Therefore, district-free cities with reception centres for asylum seekers have relatively high external migration gains and high internal migration losses at the same time. Due to their relatively small population, this reverse trend is particularly pronounced for district-free cities with a population density of less than 150 inhabitants $/ \mathrm{km}^{2}$, but negligible in terms of the impact on population size.

The population development of district-free cities differs considerably in 2000 09 and 2010-14 (see Fig. 1 and Table 4) due to a change in spatial population movements when looking at migrants' citizenship (see Fig. 2). From 2000-09, internal migration balances of German and foreign nationals determine the increase in population figures in district-free cities, whereas the balance of the German population is most important according to the regression analysis in Table 5 . While Germans' external migration balance might correlate negatively with the average annual growth, it does not increase the variance explained significantly and is thus not taken into account due to heteroscedasticity. From 2010-14, only the internal migration balance of Germans has a statistically significant impact on population development, although the balances of external migration are weakly linked to the trend of number of inhabitants (foreign nationals: +0.285 ; Germans: -0.261 ). The clear decline in the variance explained for the time period between 2010 and 2014 also indicates that in this phase, the causalities regarding population development are differentiated on the basis of migration balances. In both time periods, higher positive internal migration balances are to be expected where the job market favours the creative industries and company-related services, if the skills of employees were above average, if the number of available places for students in higher education was high and if the land prices increased between 2008/09 and 2012/13.

The migration balances included in the calculations result from the sum of agespecific balances, whose temporal dynamics and spatial differentiation in turn give a deeper insight into motives for migration and into the attractiveness of districtfree cities for various age groups. Thus, migration balances show the following motives (Milbert/Sturm 2016):

- Under 18-year-olds: mainly housing-oriented motives, meaning members of private households in the expansion phase which are striving for home ownership or at least an increase in their living space and - due to rising land prices - are also driven by price-sensitive aspects in their migration decisions.

- 18-to under 25-year-olds: education-oriented motives, meaning educational migrants who are predominantly looking for district-free cities with further education institutions and/or opportunities for vocational training. 
Tab. 5: $\quad$ Regression model for population growth of large cities (2000-14)*

\begin{tabular}{|c|c|c|c|}
\hline \multirow[b]{2}{*}{ Independent variable* } & \multicolumn{3}{|c|}{$\begin{array}{l}\text { Dependent variable } \\
\text { Average annual population growth of } \\
\text { district-free cities in \%o }\end{array}$} \\
\hline & Regression coefficient & $\beta$-coefficient & $\mathrm{n}$ \\
\hline & \multicolumn{3}{|c|}{$(2000-09)$} \\
\hline Constant & -0.204 & & 98 \\
\hline \multicolumn{4}{|l|}{ Internal migration balance of Germans } \\
\hline per 1,000 German inhabitants (2003-09) & 0.110 & 0.818 & \\
\hline \multicolumn{4}{|l|}{ Internal migration balance of foreigners } \\
\hline per 1,000 foreign inhabitants (2003-09) & 0.010 & 0.168 & \\
\hline \multirow[t]{2}{*}{ Variance extracted } & \multicolumn{3}{|c|}{$77.3 \%$} \\
\hline & \multicolumn{3}{|c|}{$(2010-14)$} \\
\hline Constant & 0.275 & & 100 \\
\hline \multicolumn{4}{|l|}{ Internal migration balance of Germans } \\
\hline per 1,000 German inhabitants (2010-13) & 0.088 & 0.659 & \\
\hline Variance extracted & \multicolumn{3}{|c|}{$43.5 \%$} \\
\hline
\end{tabular}

Heteroscedasticity is neither present when following the method of Glesjer (Backhaus et al. 2016: 104), nor is there a significant correlation between the estimated values for regression and residuals. The number of district-free cities varies as a result of the exclusion of those cities from the analysis which show extreme values due to reception centres for asylum seekers.

Source: BBSR 2016a; own calculation

- 25- to under 30-year-olds: workplace-oriented motives, meaning labour migrants who are looking for a job after graduation and prefer cities with good job markets and differentiated employment opportunities.

- 65-year-olds and older: retirement motives, meaning a tendency to leave district-free cities in favour of less densely populated districts after retirement.

\subsubsection{Internal and External Migration of the German Population by Age}

In both timeframes (2005-09 and 2010-13), population growth in district-free cities was driven by the internal migration gains of German citizens (see Table 5). This positive development can be attributed to the in-migration surpluses of young adults aged 18 to 30 (correlation coefficient of at least +0.6 ). The internal migration balances of older people, however, do not have any effect on the population development, neither in the first nor in the second timeframe, whereas the internal migration balances of under-18-year-olds changed from ambivalent in the first phase (coefficient: -0.122) to significantly negative in the second phase (coefficient: -0.406 ).

The internal migration balances of different age groups are illustrative of the appeals of cities of different sizes (see Table 6). For people aged 18-25, the larger the city, the greater the migration surplus, even more so between 2010 and 2013. It can 
be assumed that this recent development was mainly influenced by the suspension of compulsory military service in 2011, by the reduction of secondary school years and, as a consequence, by double graduation classes in almost all federal states after 2012 (see chapter 2). The introduction of the secondary residence tax in several university cities since around 2005 also increased the number of inhabitants, simply due to the fact that many students re-registered their secondary residence in the university city as their primary residence in order to avoid tax payments, and were thus registered as new inhabitants. Consequently, the urban population grows, although no "real" immigration has occurred (Engler 2013: 16). Universities in cities with less than 500,000 inhabitants benefited in particular from the noticeable increase in the number of freshmen. The distribution of the balances according to size categories indicates a metropolitanisation process, which has been weakening since 2010 (see Table 6). Compared to this age group, the balance of labour migrants aged 25-30 is characterised by a much higher tendency "up the size hierarchy". Only the metropolitan cities had in-migration surpluses in both time periods, whereas since 2010, some district-free cities of other sizes have been experiencing increasing migration losses.

Tab. 6: Balance of internal migration rates of German nationals by city size and age group $(2005-09,2010-13)^{1}$

\begin{tabular}{|c|c|c|c|c|c|c|c|c|c|c|c|}
\hline \multirow{4}{*}{$\begin{array}{l}\text { District-free } \\
\text { cities, number } \\
\text { of inhabitants }\end{array}$} & \multicolumn{10}{|c|}{ Internal migration rate per 1,000} & \multirow[t]{4}{*}{$\mathrm{n}$} \\
\hline & \multicolumn{2}{|c|}{$\begin{array}{c}\text { Less than } 18 \\
\text { years }\end{array}$} & \multicolumn{2}{|c|}{$\begin{array}{c}18 \text { to } 25 \\
\text { years }\end{array}$} & \multicolumn{2}{|c|}{$\begin{array}{c}25 \text { to } 30 \\
\text { years }\end{array}$} & \multicolumn{2}{|c|}{$\begin{array}{c}65 \text { years and } \\
\text { older }\end{array}$} & \multicolumn{2}{|c|}{$\begin{array}{l}\text { All age } \\
\text { groups }\end{array}$} & \\
\hline & 2005- & 2010- & $2005-$ & 2010- & 2005- & $2010-$ & 2005- & 2010- & $2005-$ & $2010-$ & \\
\hline & 09 & 13 & 09 & 13 & 09 & 13 & 09 & 13 & 09 & 13 & \\
\hline \multicolumn{12}{|l|}{ Large cities } \\
\hline$\geq 500,000$ & -6.7 & -8.3 & 60.9 & 61.2 & 37.4 & 31.5 & -3.2 & -2.5 & 4.5 & 3.5 & 12 \\
\hline $\begin{array}{l}200,000< \\
500,000\end{array}$ & -4.6 & -5.9 & 51.6 & 60.8 & 2.6 & -3.2 & -2.4 & -1.5 & 1.5 & 1.9 & 22 \\
\hline $\begin{array}{l}100,000< \\
200,000\end{array}$ & -2.7 & -4.6 & 40.3 & 46.7 & -1.3 & -1.8 & -1.9 & -1.4 & 1.2 & 1.1 & 28 \\
\hline \multicolumn{12}{|l|}{ Cities } \\
\hline$<100,000$ & -1.5 & -3.0 & 18.5 & 29.7 & -16.0 & -16.5 & 0.7 & 1.5 & -0.0 & 0.7 & 40 \\
\hline $\begin{array}{l}\text { All district- } \\
\text { free cities }\end{array}$ & -4.9 & -6.6 & 50.4 & 55.4 & 17.9 & 13.5 & -2.3 & -1.6 & 2.7 & 2.4 & 102 \\
\hline
\end{tabular}

1 District-free cities with extreme values on migration balance are not considered.

Source: BBSR 2016a; own calculation

Due to heteroscedasticity, it is difficult to determine the influence of specific characteristics of district-free cities on the internal migration balances of 18-to-25and 25-to-30-year-olds. Nevertheless, correlation analyses for both time periods show that with increasing migration rates in both age groups (see Table 7,8 ), the proportion of employees in the business service sector and creative industry who 
Tab. 7: Correlation (Spearman's Rho') between the balance of internal migration by selected age groups and variables characterising specific dimensions of district-free cities, 2005-09

\begin{tabular}{|c|c|c|c|}
\hline \multirow[t]{2}{*}{ Variable } & \multicolumn{3}{|c|}{ Balance of internal migration rate per 1,000} \\
\hline & Less than 18 years & 18 to 25 years & 25 to 30 years \\
\hline \multicolumn{4}{|l|}{$\begin{array}{l}\text { Employment structure (proportion } \\
\text { of employees who are subject to } \\
\text { social insurance contributions in) }\end{array}$} \\
\hline $\begin{array}{l}\text { Business-related services (in \%, } \\
\text { 2009) }\end{array}$ & $-0.402 * *$ & $+0.516^{* *}$ & $+0.496 * *$ \\
\hline Creative industries (in \%) ${ }^{2}$ & $-0.430 * *$ & $+0.617^{* *}$ & $+0.391 * *$ \\
\hline $\begin{array}{l}\text { Knowledge-driven industries } \\
\text { (in \%, 2009) }\end{array}$ & - & - & - \\
\hline \multicolumn{4}{|l|}{ Labour market } \\
\hline Unemployment (in \%) $)^{3}$ & - & $-0.222 *$ & $-0.448 * *$ \\
\hline \multicolumn{4}{|l|}{ Education } \\
\hline $\begin{array}{l}\text { Highly qualified employees per } \\
1,000 \text { employees aged } 30-35^{4}\end{array}$ & $-0.506^{* *}$ & $+0.840 * *$ & $+0.504^{* *}$ \\
\hline $\begin{array}{l}\text { Number of students per } 1,000 \\
\text { inhabitants }^{3}\end{array}$ & $-0.477 * *$ & $+0.762 * *$ & - \\
\hline \multicolumn{4}{|l|}{ Housing market } \\
\hline $\begin{array}{l}\text { Residential properties completed } \\
\text { (in \%) }{ }^{3}\end{array}$ & - & $-0.233^{*}$ & $+0.315^{* *}$ \\
\hline Building land prices $(2008 / 09)$ & - & $+0.243^{*}$ & $+0.440^{* *}$ \\
\hline $\begin{array}{ll}1 & \text { level of significance: }{ }^{* *} \mathrm{p}<0.01 ; \\
2 & \text { average of } 2008 \text { and } 2009 ; \\
3 & \text { average of } 2000 \text { and } 2009 ; \\
4 & \text { average of } 2005 \text { and } 2009\end{array}$ & $\mathrm{*} p<0.05$ & & \\
\hline
\end{tabular}

Source: BBSR 2016a/b; own calculation

contribute to social insurance and the importance of highly-skilled workers with academic degrees rise. Such cities are also characterised by high land prices. District-free cities with relatively high numbers of places at universities for students compared to their number of inhabitants attract many young people, whereas for 25-to-30-year-old labour migrants, cities with low unemployment rates and high construction activity are particularly attractive.

The parallel classification of district-free cities by internal migration gains and losses regarding both age groups within the time period of 2005-13 provides further insights into the factors influencing the balances. All metropolitan cities - except for Bremen - achieve in-migration surpluses for educational and labour migrants (e.g. Berlin, Dortmund, Dresden, Essen, Frankfurt/Main, Hamburg, Cologne, Munich, Stuttgart) due to their large and differentiated labour markets as well as educational facilities and thus their diverse workplace opportunities, not only for university graduates. There are a number of university cities belonging to this 
Tab. 8: Correlation (Spearman's Rhoํ) between the balance of internal migration by selected age groups and variables characterising specific dimensions of district-free cities, 2010-13

\begin{tabular}{|c|c|c|c|}
\hline \multirow[t]{2}{*}{ Variable } & \multicolumn{3}{|c|}{ Balance of internal migration rate per 1,000} \\
\hline & Less than 18 years & 18 to 25 years & 25 to 30 years \\
\hline \multicolumn{4}{|l|}{$\begin{array}{l}\text { Employment structure (proportion } \\
\text { of employees who are subject to } \\
\text { social insurance contributions in) }\end{array}$} \\
\hline Business-related services (in \%) ${ }^{2}$ & $-0.494^{* *}$ & $+0.527 * *$ & $+0.414^{* *}$ \\
\hline Creative industries (in \%) $)^{2}$ & $-0.476^{* *}$ & $+0.580^{* *}$ & $+0.367^{* *}$ \\
\hline $\begin{array}{l}\text { Knowledge-driven industries } \\
\text { (in \%) }{ }^{2}\end{array}$ & - & $-*$ & - \\
\hline \multicolumn{4}{|l|}{ Labour market } \\
\hline Unemployment (in \%) $)^{2}$ & - & - & - \\
\hline \multicolumn{4}{|l|}{ Education } \\
\hline $\begin{array}{l}\text { Highly qualified employees per } \\
1,000 \text { employees aged } 30-35^{2}\end{array}$ & $-0.700 * *$ & $+0.843^{* *}$ & $+0.330 * *$ \\
\hline $\begin{array}{l}\text { Number of students per } 1,000 \\
\text { inhabitants }\end{array}$ & $-0.599 * *$ & $+0.782^{* *}$ & $-0.217^{*}$ \\
\hline \multicolumn{4}{|l|}{ Housing market } \\
\hline $\begin{array}{l}\text { Residential properties completed } \\
(\text { in } \%)^{2}\end{array}$ & $-0.236^{*}$ & $+0.427^{*}$ & $+0.333^{* *}$ \\
\hline Building land prices $(2013 / 14)$ & $-0.433^{* *}$ & $+0.322 * *$ & $+0.527^{* *}$ \\
\hline $\begin{array}{l}\text { Change in building land prices } \\
(2008 / 09-2013 / 14 ; \text { in \%) }\end{array}$ & $-0.228 *$ & $+0.355^{* *}$ & $+0.234^{* *}$ \\
\hline
\end{tabular}

Source: BBSR 2016a/b; own calculation

group of district-free cities which host numerous research facilities of national and international prominence, company headquarters, knowledge-driven industries or business-related services (e.g. Bonn, Brunswick, Coburg, Darmstadt, Erlangen, Karlsruhe, Mainz, Münster, Ulm, Wolfsburg). Some district-free cities located close to a metropolitan city are attractive residential locations for commuters to major cities (e.g. Fürth, Offenbach/Main, Potsdam). District-free cities with inflows of educational migrants and outflows of labour migrants are relatively heterogeneous. They stand out with their combination of higher education institutions and a regional labour market which cannot provide enough workplaces for the graduates. These include district-free cities in East Germany that experienced an expansion of student place capacities, such as Erfurt, Jena, Magdeburg or Rostock. In West Germany, examples include Bayreuth, Flensburg, Kaiserslautern, Kassel or Passau, where universities were built in the 1960s and 70s as catalysts for regional development. This group also includes district-free cities with comparatively high unemployment (e.g. Bremen, Duisburg, Schweinfurt, Wuppertal) or with very tight housing markets 
(Heidelberg, Freiburg). The balances in both age groups are particularly negative for cities with high unemployment, such as the Ruhr area (e.g. Gelsenkirchen, Hagen, Herne, Oberhausen), Frankfurt/Oder, Pirmasens or Salzgitter. Only six cities, including Baden-Baden, Leverkusen, Mühlheim, had losses of educational migrants and increases of labour migrants, as they are home to relatively large employers from the media, chemical and food retail industry.

The balances of internal migration rates of Germans below the age of $18 \mathrm{de}$ scribe a countertrend towards the metropolitanisation process of people age 18-30 (see Table 6). This "down the size hierarchy" development (see Table 6) is verified by significantly negative correlations in both time periods with variables (see Table 7,8 , which - according to economic structure and qualification of employees - become more and more evident with growing population numbers.

The significant losses of the German population below the age of 18 in metropolitan cities and growing balances with decreasing size of the cities indicates a suburbanisation process, which has intensified since 2010 (see Table 6). Reasons for this intensification can be found in increasing building land prices, whose median value rose moderately by 20 percent between $2008 / 09$ and 2013/14 to $193 € /$ $\mathrm{m}^{2}$ in all district-free cities, compared to a doubling of land prices to $369 € / \mathrm{m}^{2}$ in the metropolitan cities (BBSR 2016b, own calculations; Waltersbacher 2017: 5-8). It is noteworthy that in the period between 2005 and 2009, there is no significant correlation between 2008/09 building land prices and the balance of internal migration of Germans younger than 18 as an indicator for housing-oriented migration (see Table 7). In the 2010-13 time period, the balance of this age group is correlated negatively with 2013/14 land prices and their changes from 2008/09 to 2013/14. The accelerated increase in prices means that private households in the expansion phase, which want to rent or buy property in large cities, often cannot achieve their living requirements in cities with at least 100,000 inhabitants, as they cannot afford properties on offer, and this despite favourable conditions such as low loan rates and an increase in real earnings since 2010 . One alternative is the purchase of property in surrounding areas.

Even though large cities have the advantage of accessible infrastructure for older people due to agglomeration advantages and mobility offers, they experienced internal migration losses in the age group of 65 years and older between 2005 and 2013, compared to gains in smaller district-free cities (see Table 6). There are various reasons for this development, such as returning to one's place of origin or moving to scenically attractive areas with a low population density - such as the alpine foreland or coastal areas -, but also to urban areas with a high living standard, which have all location advantages of larger cities, especially if they are adapted to the specific needs of older people. Baden-Baden, Potsdam and Weimar all show consistently high in-migration surpluses in the time period between 2005 and 2013.

In the investigated time periods, district-free cities consistently experienced external migration losses of German citizens (see Table 9), which were halved in the wake of the financial crisis in 2009 as a result of higher immigration rates in combination with simultaneously declining out-migrations (2005-09: -0.9\%; 201013: $-0.4 \%$ o). Here, the age group of 25 -to-30-year-olds show the lowest rates, their 
Tab. 9: Balance of external migration rate by city size and selected age group $(2005-09,2010-13)^{1}$

\begin{tabular}{|c|c|c|c|c|c|c|c|c|c|c|c|}
\hline \multirow{4}{*}{$\begin{array}{l}\text { District-free } \\
\text { cities, number } \\
\text { of inhabitants }\end{array}$} & \multicolumn{10}{|c|}{ Rates per 1,000} & \multirow[t]{4}{*}{$\mathrm{n}$} \\
\hline & $\begin{array}{r}\text { Less th } \\
\text { yea }\end{array}$ & $\begin{array}{l}\text { han } 18 \\
\text { ars }\end{array}$ & \multicolumn{2}{|c|}{$\begin{array}{c}18 \text { to } 25 \\
\text { years }\end{array}$} & \multicolumn{2}{|c|}{$\begin{array}{c}25 \text { to } 30 \\
\text { years }\end{array}$} & \multicolumn{2}{|c|}{$\begin{array}{c}65 \text { years and } \\
\text { older }\end{array}$} & \multicolumn{2}{|c|}{$\begin{array}{l}\text { All age } \\
\text { groups }\end{array}$} & \\
\hline & $2005-$ & $2010-$ & $2005-$ & $2010-$ & $2005-$ & $2010-$ & 2005- & $2010-$ & $2005-$ & 2010 & \\
\hline & 09 & 13 & 09 & 13 & 09 & 13 & 09 & 13 & 09 & 13 & \\
\hline \multicolumn{12}{|l|}{ Large cities } \\
\hline$\geq 500,000$ & -1.1 & -0.1 & -0.0 & +0.6 & -3.0 & -2.1 & -0.2 & -0.1 & -1.0 & -0.4 & 12 \\
\hline $\begin{array}{l}200,000< \\
500,000\end{array}$ & -0.9 & -0.3 & -0.5 & -0.2 & -2.8 & -2.1 & -0.1 & -0.1 & -0.8 & -0.5 & 22 \\
\hline $\begin{array}{l}100,000< \\
200,000\end{array}$ & -1.0 & -0.2 & -0.7 & +0.1 & -2.9 & -2.0 & -0.2 & -0.1 & -0.9 & -0.4 & 28 \\
\hline \multicolumn{12}{|l|}{ Cities } \\
\hline$<100,000$ & -1.2 & -0.4 & -1.1 & -0.5 & -3.1 & -2.2 & -0.2 & -0.1 & -0.9 & -0.5 & 40 \\
\hline $\begin{array}{l}\text { All district- } \\
\text { free cities }\end{array}$ & -1.1 & -0.2 & -0.4 & +0.2 & -2.9 & -2.1 & -0.2 & -0.1 & -0.9 & -0.4 & 102 \\
\hline
\end{tabular}

1 District-free cities with extreme values on migration balance are not considered.

Source: BBSR 2016a; own calculation

negative balance lessened after 2009 (2005-09: -2.9\%; 2010-13: -2.1\%o), but is still far from that of the other age groups. An explanation could be that highly-qualified young adults with a migrant background emigrate to their other country of citizenship. Consequently, the balance of Germany with Turkey has been negative since 2006, certainly also because of the positive economic developments in Turkey up until 2013 and the good employment opportunities for skilled workers of Turkish origin from German companies (Hanewinke/ 2012: 3). Overall, the negative effects of external migration losses on urban population development are negligible, especially in comparison to the rates of internal migration balances, irrespective of the time period or the size of cities.

\subsubsection{Internal and External Migration of the Foreign Population by Age}

District-free cities predominantly register internal migration gains of foreign citizens (see Table 10). The in-migration surpluses of under-30-year-olds were overproportionately high in both time periods, while older people tended to give up their place of residence in the city. In the period of 2005-09, metropolitan cities were highly attractive for foreigners age 18-30, not so, however, for children and adolescents or for people age 65 and older. From 2010 to 2013, the in-migration surpluses for the age groups under 30 in large cities with less than 500,000 inhabitants increased considerably, in particular, small district-free cities became more attractive. At the same time, internal migration increases of foreigners in metropolitan cities decreased in all age groups. For young adults, the metropolitanisation process in the 
Tab. 10: Balance of internal migration of foreign citizens by city size and age group $(2005-09,2010-13)^{1}$

\begin{tabular}{|c|c|c|c|c|c|c|c|c|c|c|c|}
\hline \multirow{2}{*}{$\begin{array}{l}\text { District-free } \\
\text { cities, number } \\
\text { of inhabitants }\end{array}$} & \multicolumn{10}{|c|}{ Rates per 1,000} & \multirow[t]{2}{*}{$\mathrm{n}$} \\
\hline & $\begin{array}{c}\text { Less } \\
\text { ye } \\
2005- \\
09\end{array}$ & $\begin{array}{l}\text { han } 18 \\
\text { ars } \\
2010- \\
13\end{array}$ & $\begin{array}{c}18 \\
y e \\
2005 \\
09\end{array}$ & $\begin{array}{l}25 \\
\text { ars } \\
2010- \\
13\end{array}$ & $\begin{array}{r}25 t \\
\text { ye } \\
2005- \\
09\end{array}$ & $\begin{array}{l}\text { o } 30 \\
\text { ars } \\
2010- \\
13\end{array}$ & $\begin{array}{r}65 \text { yea } \\
\text { ol } \\
2005- \\
09\end{array}$ & $\begin{array}{l}\text { ars and } \\
\text { der } \\
2010- \\
13\end{array}$ & $\begin{array}{r}\text { All } \\
\text { gro } \\
2005- \\
09\end{array}$ & $\begin{array}{l}\text { age } \\
\text { oups } \\
2010- \\
13\end{array}$ & \\
\hline \multicolumn{12}{|l|}{ Large cities } \\
\hline$\geq 500,000$ & 2.8 & 1.0 & 14.5 & 9.7 & 11.7 & 7.3 & -0.5 & 1.1 & 4.5 & 1.0 & 12 \\
\hline $\begin{array}{l}200,000< \\
500,000\end{array}$ & 4.9 & 14.4 & 11.7 & 21.1 & 0.7 & 4.5 & 0.1 & -0.5 & 2.6 & 5.2 & 22 \\
\hline $\begin{array}{l}100,000< \\
200,000\end{array}$ & 3.1 & 14.5 & 12.9 & 19.6 & 1.4 & 8.3 & -0.8 & 0.5 & 2.4 & 5.8 & 28 \\
\hline \multicolumn{12}{|l|}{ Cities } \\
\hline$<100,000$ & 3.1 & 21.7 & 8.7 & 25.0 & -6.0 & 8.6 & -0.7 & 1.2 & 1.0 & 9.2 & 40 \\
\hline $\begin{array}{l}\text { All district- } \\
\text { free cities }\end{array}$ & 3.4 & 7.6 & 13.2 & 14.9 & 6.7 & 6.9 & -0.4 & -0.6 & 3.5 & 3.2 & 102 \\
\hline
\end{tabular}

1 District-free cities with extreme values on migration balance are not considered.

Source: BBSR 2016a; own calculation

time period between 2005 and 2009 started changing to a "down the size hierarchy" trend, which grew for the under 18-year-olds in 2005-09, and subsequently became increasingly clear.

A further stone in the mosaic of metropolitanisation is added by the distribution of external migration balances of the foreign population (see Table 11). In districtfree cities, irrespective of their size, the gains for the under-30-year-olds were almost seven times higher in 2010-13 than in 2005-09, and even higher than that for some age groups and city size categories. Only for older foreigners, a relocation beyond German borders is likely, a trend that has strengthened since 2010. In both periods, a concentration process can only partially be identified, as the balances of the under 30-year-olds were overproportionately high for metropolitan cities. But also in district-free cities with less than 100,000 inhabitants, the balances increased strongly. This development indicates a combination of migration both down and up the "size hierarchy".

These findings on migration balances of the foreign population give rise to a number of different explanatory approaches which, however, cannot be proven adequately with the data available due to factors such as multicollinearity. In the time period from 2005 to 2009, the correlations between external migration balances of foreigners and location-specific characteristics of district-free cities are quite weak.

18-to-30-year-olds are the only age group for which there is an indication that they predominantly prefer to move to district-free cities whose economic structure promises a relatively good labour market. The economic recovery in Germany since 2010 has stimulated a significant increase in immigration from abroad. It can be 
Tab. 11: Balance of external migration of foreign citizens by city size and age group $(2005-09,2010-13)^{1}$

\begin{tabular}{|c|c|c|c|c|c|c|c|c|c|c|c|}
\hline \multirow{3}{*}{$\begin{array}{l}\text { District-free } \\
\text { cities, number } \\
\text { of inhabitants }\end{array}$} & \multicolumn{10}{|c|}{ Rates per 1,000} & \multirow[t]{3}{*}{$\mathrm{n}$} \\
\hline & \multicolumn{2}{|c|}{$\begin{array}{l}\text { Less than } 18 \\
\text { years } \\
2005-2010-\end{array}$} & \multicolumn{2}{|c|}{$\begin{array}{c}18 \text { to } 25 \\
\text { years }\end{array}$} & \multicolumn{2}{|c|}{$\begin{array}{c}25 \text { to } 30 \\
\text { years }\end{array}$} & \multicolumn{2}{|c|}{$\begin{array}{c}65 \text { years and } \\
\text { older }\end{array}$} & \multicolumn{2}{|c|}{$\begin{array}{l}\text { All age } \\
\text { groups }\end{array}$} & \\
\hline & $\begin{array}{c}2005- \\
09\end{array}$ & & $\begin{array}{c}2005- \\
09\end{array}$ & $\begin{array}{l}2010- \\
13\end{array}$ & $\begin{array}{c}2005- \\
09\end{array}$ & $\begin{array}{l}2010- \\
13\end{array}$ & $\begin{array}{c}2005- \\
09\end{array}$ & $\begin{array}{c}2010- \\
13\end{array}$ & $\begin{array}{l}2005- \\
09\end{array}$ & $\begin{array}{c}2010- \\
13\end{array}$ & \\
\hline \multicolumn{12}{|l|}{ Large cities } \\
\hline$\geq 500,000$ & 13.9 & 58.0 & 88.8 & 156.3 & 24.0 & 91.9 & -17.0 & -16.4 & 6.8 & 43.8 & 12 \\
\hline $\begin{array}{l}200,000< \\
500,000\end{array}$ & 8.9 & 50.4 & 58.4 & 108.2 & 9.5 & 65.5 & -9.6 & -11.8 & 5.1 & 34.7 & 22 \\
\hline $\begin{array}{l}100,000< \\
200,000\end{array}$ & 9.5 & 47.9 & 61.4 & 117.3 & 15.8 & 72.1 & -12.0 & -11.5 & 5.1 & 38.4 & 28 \\
\hline \multicolumn{12}{|l|}{ Cities } \\
\hline$<100,000$ & 9.3 & 50.0 & 67.8 & 136.8 & 6.6 & 73.3 & -7.3 & -10.1 & 6.3 & 40.4 & 40 \\
\hline $\begin{array}{l}\text { All district- } \\
\text { free cities }\end{array}$ & 11.6 & 54.1 & 75.3 & 137.5 & 18.5 & 82.2 & -13.7 & -14.1 & 6.1 & 40.7 & 102 \\
\hline
\end{tabular}

assumed that immigration from the 2004/07 EU accession states were most likely aimed at the large regional labour markets with their differentiated demand for economic sectors and qualification of employees. Consequently, the correlation coefficients of 18-to-25-year-olds are significantly positive - and a little less pronounced for the 25-30 age group - with the proportion of employees in the creative industry who are subject to social insurance contributions $(+0.318)$, highly-skilled workers $(+0.568)$ and employees with an academic degree $(+0.615)$.

This concentration in favour of metropolitan cities is mitigated by the effectiveness of social networks. The positive development on the labour market in Germany certainly is a crucial pull factor for potential labour migrants from other EU member states. However, the correlation between external migration balances of foreigners and the average unemployment rate in $2010-13$ is not significantly different from zero. For example, Bochum, Dortmund and Essen in the Ruhr area, Frankfurt/Main, Nuremberg and Stuttgart in southern Germany registered in-migration surpluses of 30 to 44 per mille in 2010-13, but the unemployment rate in the Ruhr area ranged from 9 to almost 13 percent, whereas in the southern German cities it amounted to less than 5.5 percent. The less important the situation on the labour market is as a factor directly influencing the spatial distribution of international migration, the greater the importance of social networks for immigration, for example by means of chain migration. This leads to a persistence of spatial patterns - in the case of Italians, for example, especially in the south-west of Germany (Gans/Schlömer 2014: 150) or in the case of Turks in the Ruhr area -, which even more than 40 years after 
the recruitment stop reflect peculiarities of former but not necessarily of current labour markets and economic structures.

Changes in places of residence linked to the distribution of asylum seekers follow certain criteria, such as availability of housing, access to social infrastructures etc. and structures of the labour market that are statistically hard to capture. For example, district-free cities with reception centres for asylum seekers are characterised by high external migration gains, such as Neumünster with +725 per mille, Trier with +629 per mille, Chemnitz with +626 per mille, Karlsruhe with +327 per mille or Eisenach with 120 per mille. At the same time, however, they are also characterised by high internal migration losses as a result of the relocation of asylum seekers to other municipalities, which is handled differently from one federal state to the next. The allocation of asylum seekers is formally recorded as in-migration.

In the time period between 2005 and 2009, the internal migration of foreign citizens was predominantly motivated by labour market trends. The rate for all foreigners as well as the rate for the respective age group of the under 30 -year-olds correlates significantly negatively with the average unemployment rate in this phase. This correlation is no longer verifiable for the 2010-13 time period. The correlation coefficients indicate that foreign citizens leave district-free cities with a corporate structure fostering economic development (high importance of business-related services, creative industries, highly-skilled workers), and households with foreign members in the expansion phase leave district-free cities due to high building land prices in particular. This is accompanied by the observation that for 2010-13 in comparison to 2005-09, cities with a declining population are gaining in importance as internal migration destinations for foreign nationals. The reason behind this development could be the decentralised distribution of asylum seekers after their registration in the reception centres. Irrespective of this, taking into account the high external migration gains of metropolitan cities, one could expect a saturation effect on the regional labour and housing markets, following Light and von Scheven (2006). The extraordinary increase in immigration from abroad to metropolitan cities (see Table 11) reduces the employment opportunities for foreigners in specific labour market segments over time, and at the same time reduces supply in those urban housing markets, for which households with members of foreign origin have increased access opportunities. In addition, accommodation costs rise as the growing demand for low-cost/affordable living space meets limited supply. The resulting bottlenecks could ultimately lead to a situation in which mobile foreign jobseekers divert to smaller district-free cities and thus initiate a "down the size hierarchy" trend (see Table 10). It should be considered that the economic recovery after 2010 not only had a positive effect on the labour markets of metropolitan cities, but was also measurable in the urban system as a whole, even in the smaller district-free cities. Households with members of foreign origin who have been living in Germany for a long time, have - on the basis of their social networks - information advantages over those only just arriving from abroad. They orient themselves locally and are less dependent on information about the metropolitan cities with their large regional markets and numerically large minorities (see Table 11). 


\section{Conclusion}

Overall, this paper shows that reurbanisation results from the superimposition of differently combined spatial population movements - further differentiated by age and citizenship -, and these express different motives for living in cities or in more rural areas. Migration gains are particularly evident in cities in which the economic transition towards the knowledge economy has progressed (Florida 2002; Storper) Scott 2009; Geppert/Gornik 2010), in which the labour market is relaxed and in which a wide range of educational opportunities are available (Buzar et al. 2007). Young people are drivers of population growth (Haase et al. 2010), when looking at internal migration, it is the 18-to-30-year-olds, when looking at external migration, it is the under-30-year-olds (Birch 2005; Fisherman 2005; Rérat 2012). Since the economic and financial crisis, the latter have noticeably reinforced urban population growth in Germany. The dynamics of these migration processes are not only dependent upon location advantages and disadvantages, but also upon conditions that play a role at the national and international levels, such as the significantly improved economic situation in Germany compared to other EU member states or the political crises in the Middle East and Africa.

The results of this study also demonstrate the high complexity of urban systems, whose elements follow their own logic in their development and at the same time, the balanced urban system in Germany forms the framework (Sander 2018). Due to federalism with its historical roots and the division of Germany after the Second World War, there is no central metropolis in Germany, but rather several metropolises, which compete with one another for the establishment of corporate headquarters or high-level state functions. Accordingly, development "up the size hierarchy" (Frey 1988) within the urban system is rather weak. Besides the different dynamics of migration balances by age and citizenship, the fact that there are cities of medium size with a high standard of living, such as Darmstadt, Freiburg im Breisgau, Osnabrück or Postdam, also contributes to this.

There are some aspects that this paper could not deal with, as the necessary data bases were unavailable. This applies to the effects of social change on urban growth in particular. Furthermore, the role of urban development projects were beyond the scope of this paper.

Looking at the results, the following selected further questions can be asked:

One aspect refers to the interdependence between internal and external migration, differentiated by age and citizenship. Questions essentially relate to decisions about residential locations in the course of life, especially at the turning points between individual life cycle phases. Regarding immigration from abroad, the effects of immigrant networks are of interest, as newly arriving immigrants orient themselves toward existing ethnic or familial structures, which are often located in socially disadvantaged neighbourhoods with an above-average proportion of foreigners and high proportions of households receiving welfare support (BBSR 2017). With regard to questions on the integration of migrants, it would be interesting to know whether immigrants who have recently moved into such neighbourhoods move out again after a certain period of time. Can this be explained by the satura- 
tion concept of Light and von Scheven (2006)? For asylum seekers, there are certain restrictions upon arrival in Germany with respect to decisions about the residential location. They are first allocated to a federal state, and then assigned to reception centres. Which factors, e.g. the location of the centre or migrant networks, affect the subsequent residential choices when the asylum seeker leaves the centre? Can these in any way be compared to residential choices of late resettlers, who came to Germany from Russia in the early 1990s?

In the context of this paper, an intensification of suburbanisation - dependant on the size of the cities - could be expected for the German citizens in the future (Milbert/Sturm 2016; Simons/Weiden 2016), a primary cause being, among others, bottlenecks on the housing market. According to Florida (2017), excessive housing prices and the construction of micro-apartments threaten "urban revival" in the United States. This leads to the question of which concepts growing cities are planning to implement in order to cope with the challenges of displacement among low-income households. One could summarise this with some bullet points as follows: vacant plots in cities are not sufficient for building new housing, high-rise buildings are not in demand, the designation of new housing development areas is environmentally questionable and limited in scope. In addition, investing in affordable housing for financial reasons is not very attractive despite government grants. Municipal housing associations, for example, take on an important function in this context. Solutions might also be found in regional co-operations between core cities and surrounding districts or municipalities. In suburban areas, there might still be space available, however, environmental concerns should also be raised here, and thus, settlement areas with a social and technical infrastructure as well as good transport connections should be regionally defined. There is a need for cross-municipal cooperation in order to meet the changing demands of housing supply, social and cultural services and infrastructures (Peter 2010). When setting strategies to achieve these goals, securing affordable living space should be of high importance so as to counteract the displacement of low-income groups. How these strategies are set also depends on local circumstances in municipalities, as Brombach et al. (2015) show using the examples of Stuttgart, Mannheim and Freiburg.

A further consequence of population growth is that large cities need to invest further in their social infrastructures. On the one hand, since 2010, migrants with foreign citizenship have increased in all urban neighbourhoods, but overproportionately in socially disadvantaged neighbourhoods. On the other hand, the birth deficit has been reversing since 2010 in district-free cities, in some cases with high migration gains, there are birth surpluses due to age-related reasons. This implies that education and care facilities must be expanded as of 2015, especially in view of the great challenges of integration following the large influx of approximately 2.1 million immigrants and an external migration gain of 1.1 million people with a simultaneously growing diversity of the population structure regarding country of origin, ethnicity, education, legal status and social situation (Vertovec 2007). Since 2010, urban population growth has been strongly driven by external migration. At the same time, a growing suburbanisation process among German inhabitants can be observed (see Table 5, Busch 2016), which could more than cancel out migration 
gains, especially those of the 18-to-30-year-olds in the face of demographic change (Schmitz-Veltin 2015).

\section{References}

Aring, Jürgen 2005: Bodenpreise und Raumentwicklung. In: Geographische Rundschau 57,3: 28-34.

Backhaus, Klaus et al. 2016: Multivariate Analysemethoden. Eine anwendungsorientierte Einführung. Berlin/Heidelberg: Springer Gabler [doi: 10.1007/978-3-662-46076-4].

BAMF (Bundesamt für Migration und Flüchtlinge) 2017: Aktuelle Zahlen zu Asyl. Ausgabe September 2017 [http://www.bamf.de/SharedDocs/Anlagen/DE/Downloads/ Inothek/ Statistik/Asyl/aktuelle-zahlen-zu-asyl-september-2017.pdf?__blob=publicationFile, 23.10.17].

BBSR (Bundesinstitut für Bau, Stadt- und Raumforschung) 2016a: Laufende Raumbeobachtung des BBSR. Spezifischer Datensatz. Bonn.

BBSR (Bundesinstitut für Bau, Stadt- und Raumforschung) 2016b: Laufende Raumbeobachtung des BBSR. Bonn.

BBSR (Bundesinstitut für Bau, Stadt- und Raumforschung) 2017: Zuwanderung findet überall in der Stadt statt - aber ungleich. In: Informationen aus der Forschung des BBSR 5: 4 [http://www.bbsr.bund.de/BBSR/DE/Veroeffentlichungen/BBSRInfo/2017/ bbsr-info-5-2017-dl.pdf?_blob=publicationFile\&v=2, 05.02.2018].

Birch, Eugenie L. 2005: Who Lives Downtown. The Brookings Institutions. Living Cities Census Series. Washington.

BMI (Bundesministerium des Innern) (Ed.): 2016: Migrationsbericht des Bundesamtes für Migration und Flüchtlinge im Auftrag der Bundesregierung. Migrationsbericht 2015. Berlin: KonzeptQuartier.

Brake, Klaus 2012: Reurbanisierung - Interdependenzen zum Strukturwandel. In: Brake, Klaus; Herfert, Günter (Eds.): Reurbanisierung. Materialität und Diskurs in Deutschland. Wiesbaden: Springer VS: 22-33 [doi: 10.1007/978-3-531-94211-7_2].

Braun, Boris; Viehoff, Valerie 2012: London 2012: Olympische Spiele als nachhaltiger Umpulsgeber für die Stadterneuerung. In: Geographische Rundschau 64,6: 4-11.

Brombach, Karoline; Fricke, Axel; Jessen, Johann 2015: Kommunale Strategien im Vergleich. Urbanes Wohnen in Stuttgart, Mannheim und Freiburg. In: Fricke, Axel; Siedentop, Stefan; Zakrzewski, Philipp (Eds.): Reurbanisierung in baden-württembergischen Stadtregionen. Beiträge zur Stadtentwicklung in Deutschland. Arbeitsberichte der ARL 14. Hannover: Verlag der ARL: 118-170.

Brühl, Hasso et al. 2005: Wohnen in der Innenstadt - eine Renaissance? In: Difu-Beiträge zur Stadtforschung 41. Berlin: Deutsches Institut für Urbanistik.

Busch, Roland 2016: Inländische Wanderungen in Deutschland - wer gewinnt und wer verliert? In: Zeitschrift für Immobilienökonomie 2,2: 81-101 [doi: 10.1365/s41056-0160012-3].

Buzar, Stefan et al. 2007: Splintering Urban Populations: Emergent Landscapes of Reurbanisation in Four European Cities. In: Urban Studies 44,4: 651-677 [doi: 10.1080/00420980601185544]. 
Cheshire, Paul 1995: A New Phase of Urban Development in Western Europe? The Evidence for the 1980s. In: Urban Studies 32,7: 1045-1063 [doi: 10.1080/004209895500 12564].

Engler, Philip 2013: Reurbanisierung als wissenschaftliches Konzept - Plädoyer für eine Konzeptualisierung als Bedeutungszunahme des Städtischen. In: disP - The Planning Review 49,2: 14-27 [doi: 10.1080/02513625.2013.826534].

Fishman, Robert 2005: Longer View: The Fifth Migration. In: Journal of American Journal Assoiation 71,4: 357-366 [doi: 10.1080/01944360508976706].

Florida, Richard L. 2002: The rise of the creative class: and how it's transforming work, leisure, community and everyday life. New York: Basic Books.

Florida, Richard L. 2017: The Urban Revival Is Over. New York Times, Sept 1 [https://www. nytimes.com/2017/09/01/opinion/cities-suburbs-housing-crime.html, 05.10.2017].

Frey, William H. 1988: The Re-Emergence of Core Region Growth: A Return to the Metropolis. In: International Regional Science Review 11,3: 261-267 [doi: 10.1177/016001768801100304].

Gans, Paul 2005: Stadt und Umland: Entwicklungen, Probleme und Gestaltungsmöglichkeiten. In: Geographische Rundschau 57,3: 10-18.

Gans, Paul 2015: Reurbanisierungstypen in Deutschland: Wissensökonomie und Komponenten der Bevölkerungsentwicklung (2004-2010). In: Fricke, Axel; Siedentop, Stefan; Zakrzewski, Philipp (Eds.): Reurbanisierung in baden-württembergischen Stadtregionen. Beiträge zur Stadtentwicklung in Deutschland. Arbeitsberichte der ARL 14. Hannover: Verlag der ARL: 11-31.

Gans, Paul; Kemper, Franz-Josef 2002: Urbanization in Germany before and after unification. In: Geyer, Hermanus S. (Ed.): International Handbook of Urban Systems. Studies of Urbanization and migration in advanced and developing countries. Cheltenham/ Northampton: Edward Elgar: 147-84.

Gans, Paul; Pott, Andreas 2018: Migration und Migrationspolitik in Europa. In: Gesemann, Frank; Roth, Roland (Eds.): Handbuch Lokale Integrationspolitik - Migration und Migrationspolitik in Europa. Integration als Herausforderung von Kommunen. Springer VS: Wiesbaden: 11-56 [doi: 10.1007/978-3-658-13409-9_2].

Gans, Paul; Schlömer, Claus 2014: Phasen internationaler Migration und ihre Auswirkungen auf Raum- und Siedlungsentwicklung in Deutschland seit 1945. In: Gans, Paul (Ed.): Räumliche Auswirkungen der internationalen Migration. Forschungsberichte der ARL 3. Hannover: Verlag der ARL: 127-161.

Geppert, Kurt; Gornig, Martin 2010: Mehr Jobs, mehr Menschen: die Anziehungskraft der großen Städte wächst. In: DIW Wochenbericht 19/2010: 2-10.

Glaeser, Edward L.; Kolko, Jed; Saiz, Albert 2001: Consumer city. In: Journal of Economic Geography 1,1: 27-50.

Hanewinkel, Vera 2012: Aus der Heimat in die Heimat? Die Abwanderung hochqualifizierter türkeistämmiger deutscher Staatsangehöriger in die Türkei. In: focus MIGRATION Kurzdossier 17: 1-8.

Haase, Annegret et al. 2010: Emergent spaces of reurbanisation: exploring the demographic dimension of inner-city change in a European Setting. In: Population, Space and Place 16,5: 443-463 [doi: 10.1002/psp.603].

Harlander, Tilman 2007: Einleitung. In: Bodenschatz, Harald et al. (Eds.): "Stadtwohnen". Geschichte - Städtebau - Perspektiven. Ludwigsburg/München: Wüstenrot Stiftung: $11-18$. 
Häußermann, Hartmut; Siebel, Walter 1987: Neue Urbanität. Frankfurt/Main. Suhrkamp.

Hesse, Markus 2010: Reurbanisierung oder Metropolisierung? Re-Urbanization or metropolization? Entwicklungspfade, Kontexte, Interpretationsmuster zum aktuellen Wandel der Großstadtregionen. In: disP - The Planning Review 46,180: 36-46 [doi: 10.1080/02 513625.2010.10557062].

Herfert, Günter; Osterhage, Frank 2012: Wohnen in der Stadt: Gibt es eine Trendwende zur Reurbanisierung? Ein quantitativ-analytischer Ansatz. In: Brake, Klaus; Herfert, Günter (Eds.): Reurbanisierung. Materialität und Diskurs in Deutschland. Wiesbaden: Springer VS: 86-112 [doi: 10.1007/978-3-531-94211-7_6].

Hirschle, Michaela; Schürt, Alexander 2008: Suburbanisierung ... und kein Ende in Sicht? Intraregionale Wanderungen und Wohnungsmärkte. In: Informationen zur Raumentwicklung 3-4: 211-228.

Jessen, Johann; Siedentop, Stefan 2018: Reurbanisierung. In: Handwörterbuch zur Stadt- und Raumentwicklung 2018 (forthcoming).

Light, Ivan; von Scheven, Elsa 2008: Mexican Migration Networks in the United States, 1980-2000. In: imr International Migration Review 42,3: 704-728 [doi: 10.1111/j.17477379.2008.00143.x].

Kabisch, Sigrun; Steinführer, Annett; Haase, Annegret 2012: Reurbanisierung aus soziodemographischer Perspektive: Haushalte und Quartierswandel in der inneren Stadt. In: Brake, Klaus; Herfert, Günter (Eds.): Reurbanisierung. Materialität und Diskurs in Deutschland. Wiesbaden: Springer VS: 113-129 [doi: 10.1007/978-3-531-94211-7_7].

Matthes, Gesa 2014: Zur Quantifizierung von Reurbanisierungstendenzen. In: Raumforschung und Raumordnung 72,4: 323-336 [doi: 10.1007/s13147-014-0300-0].

Milbert, Antonia; Sturm, Gabriele 2016: Landflucht? Gesellschaft in Bewegung. Binnenwanderungen in Deutschland zwischen 1975 und 2013. In: Informationen zur Raumentwicklung 2.2016: 121-144.

Ogden, Philip; Hall, Ray 2000: Households, Reurbanisation and the Rise of Living Alone in the Principal French Cities, 1975-1990. In: Urban Studies 37,2: 367-390 [doi: 10.1080/0042098002230].

Peter, Andreas 2010: Älter, bunter, mehr: Soziodemografischer Wandel und strategische Stadtentwicklungsplanung in der Landeshauptstadt München. In: Berichte zur deutschen Landeskunde 84,4: 349-366.

Rae, Alasdair 2013: English urban policy and the return to the city: A decade of growth, 2001-2011. In: Cities 32: 94-101 [doi: 10.1016/j.cities.2013.03.012].

Rérat, Patrick 2012: The New Demographic Growth of Cities: The Case of Reurbanisation in Switzerland. In: Urban Studies 49,5: 1107-1125 [doi: 10.1177/0042098011408935].

Rink, Dieter et al. 2012: From Long-Term Shrinkage to Re-Growth? The Urban Development Trajectories of Liverpool and Leipzig. In: Built Environment 38,2: 162-178 [doi: 10.2148/benv.38.2.162].

Rohland, Fabian 2017: Bezahlbarer Wohnraum - Die Herausforderung für Politik und Wohnungswirtschaft. In: Gans, Paul; Westerheide, Peter (Eds.): Wohnungspolitik angesichts angespannter städtischer Wohnungsmärkte. Mannheimer Schriften zu Wohnungswesen, Kreditwirtschaft und Raumplanung 17. Mannheim: Selbstverlag des Lehrstuhls für Wirtschaftsgeographie der Universität Mannheim: 31-44.

Sander, Nikola 2014: Internal Migration in Germany, 1995-2010: New Insights into EastWest Migration and Re-urbanisation. In: Comparative Population Studies 39,2: 217 246 [doi: 10.12765/CPoS-2014-04en]. 
Sander, Nikola 2018: Germany. Internal Migration within a Changing Nation. In: Champion, Tony; Cooke, Thomas; Shuttlewort, lan (Eds.): Internal Migration in the Developed World. Are we becoming less mobile? Abingdon (Oxfordshire)/New York: Routledge: 226-241.

Schindler, Felix et al. 2012: Wohnungsmarktbeobachtung 2011. Karlsruhe [https:// www.I-bank.de/lbank/download/dokument/203280.pdf, 14.11.2017].

Schmitz-Veltin, Ansgar 2015: Reurbanisierung im Kontext einer neuen Unübersichtlichkeit regionaler Entwicklungsmuster - Das Beispiel der Stadtregion Stuttgart. In: Fricke, Axel; Siedentop, Stefan; Zakrzewski, Philipp (Eds.): Reurbanisierung in baden-württembergischen Stadtregionen. Beiträge zur Stadtentwicklung in Deutschland. Arbeitsberichte der ARL 14. Hannover: Verlag der ARL: 77-95.

Scholl, Bernhard 2003: Innenentwicklung vor Außenentwicklung. Einführung in das Thema des Kongresses. In: Baden-Württemberg, Wirtschaftsministerium; Baden-Württemberg, Ministerium für Umwelt und Verkehr; Universität Karlsruhe, Institut für Städtebau und Landesplanung (Eds.): Innenentwicklung vor Außenentwicklung. Strategien, Konzepte, Instrumente. Dokumentation des Fachkongresses am 15./16. Mai 2003 in Karlsruhe. Stuttgart: Selbstverlag: 11-14.

Schürt, Alexander 2017: Zwischen Mangel und Überangebot - zunehmende Herausforderungen auf den Wohnungs- und Immobilienmärkten. In: Gans, Paul; Westerheide, Peter (Eds.): Wohnungspolitik angesichts angespannter städtischer Wohnungsmärkte. Mannheimer Schriften zu Wohnungswesen, Kreditwirtschaft und Raumplanung 18. Mannheim: Selbstverlag des Lehrstuhls für Wirtschaftsgeographie der Universität Mannheim: 3-21.

Siebel, Walter 2008: Wohnen in der Innenstadt. In: Deutsche Zeitschrift für Kommunalwissenschaften 47,1: 37-46.

Siebel, Walter 2010: Die Zukunft der Städte. In: APuZ - Aus Politik und Zeitgeschichte 17. Bonn: 3-9.

Siedentop, Stefan 2008: Die Rückkehr der Städte? Zur Plausibilität der Reurbanisierungshypothese. In: Informationen zur Raumentwicklung 3/4: 193-210.

Simons, Harald; Weiden, Lukas 2016: Schwarmverhalten, Reurbanisierung und Suburbanisierung. In: Informationen zur Raumentwicklung 3: 263-273.

Statistisches Bundesamt 2016a: Zahlen und Fakten. Gesellschaft \& Staat. Bildung, Forschung, Kultur [https://www.destatis.de/DE/ZahlenFakten/ZahlenFakten.html, 02.12.2016]

Statistisches Bundesamt 2016b: Statistisches Jahrbuch. Deutschland und Internationales. Wiesbaden.

Statistisches Bundesamt 2017: Zahlen \& Fakten. Migration, Wanderungen [https://www. destatis.de/DE/ZahlenFakten/GesellschaftStaat/Bevoelkerung/Wanderungen/Tabellen/WanderungenAlle.html, 02.05.17].

Storper, Michael; Scott, Allan J. 2009: Rethinking human capital, creativity and urban growth. In: Journal of Economic Geography 9,2: 147-167 [doi: 10.1093/jeg/lbn052]

van den Berg et al. 1982: Urban Europe. A Study of Growth and Decline. Volume 1. 162 S. Oxford u.a.: Pergamon Press.

Vertovec, Steven 2007: Super-diversity and its implications. In: Ethnic and Racial Studies 30,6: 1024-1054 [doi: 10.1080/01419870701599465].

Waltersbacher, Matthias 2017: Bauland als Engpassfaktor für mehr bezahlbaren Wohnraum. Analyse der Baulandpreise aus den Kaufpreissammlungen der Gutachterausschüsse. Bonn. 
West, Christina; Gans, Paul; Schmitz-Veltin, Ansgar 2008: Cities in space and city as place - Rethinking reurbanisation: urban, semi-urban and suburban orientiations and their impact on the choice of residence. In: Zeitschrift für Bevölkerungswissenschaft 33,3-4: 381-408 [doi: 10.1007/s12523-009-0021-6].

Prof. Dr. Paul Gans ( $₫)$. University of Mannheim. Mannheim, Germany. E-Mail: paulgans@uni-mannheim.de

URL: http://gans.vwl.uni-mannheim.de/1461.0.html 


\section{Comparative Population Studies}

wWW.comparativepopulationstudies.de

ISSN: 1869-8980 (Print) - 1869-8999 (Internet)

\section{Published by}

Prof. Dr. Norbert F. Schneider

Federal Institute for Population Research D-65180 Wiesbaden / Germany

\section{(cc) BY-SA}

2017

\section{Managing Editor}

Frank Swiaczny

\section{Assistant Managing Editor}

Katrin Schiefer

\section{Copy Editor}

(Selected Articles in German)

Dr. Evelyn Grünheid

\section{Layout}

Beatriz Feiler-Fuchs

E-mail: cpos@bib.bund.de

\section{Scientific Advisory Board}

Paul Gans (Mannheim)

Karsten Hank (Cologne)

Johannes Huinink (Bremen)

Michaela Kreyenfeld (Rostock)

Marc Luy (Vienna)

Notburga Ott (Bochum)

Peter Preisendörfer (Mainz)

Nikola Sander (Groningen)

Zsolt Spéder (Budapest)

\section{Board of Reviewers}

Martin Abraham (Erlangen)

Laura Bernardi (Lausanne)

Hansjörg Bucher (Bonn)

Claudia Diehl (Konstanz)

Andreas Diekmann (Zurich)

Gabriele Doblhammer-Reiter (Rostock)

Jürgen Dorbritz (Wiesbaden)

Anette Eva Fasang (Berlin)

E.-Jürgen Flöthmann (Bielefeld)

Alexia Fürnkranz-Prskawetz (Vienna)

Beat Fux (Salzburg)

Joshua Goldstein (Berkeley)

Sonja Haug (Regensburg)

Hill Kulu (Liverpool)

Aart C. Liefbroer (The Hague)

Kurt Lüscher (Konstanz)

Emma Lundholm (Umeå)

Nadja Milewski (Rostock)

Dimiter Philipov (Vienna)

Roland Rau (Rostock)

Tomáš Sobotka (Vienna)

Jeroen Spijker (Barcelona)

Olivier Thévenon (Paris)

Helga de Valk (Brussels)

Heike Trappe (Rostock)

Michael Wagner (Cologne) 